\title{
Limitar o Limite: modos de subsistência ${ }^{1}$
}

\author{
Alexandre Nodari ${ }^{1}$ \\ ${ }^{1}$ Universidade Federal do Paraná, Curitiba, PR, Brasil
}




\section{Resumo}

Diante da catástrofe ambiental em curso, o debate sobre os limites (materiais, planetários) vem ao primeiro plano: como lidar com eles? Como agir em relação a eles? O exercício aqui proposto é uma breve e seletiva cartografia de práticas políticas, estéticas e teóricas, que, lidas sob o manto de uma noção revisitada de subsistência e da Antropofagia de Oswald de Andrade, constituem estratégias que fogem à alternativa infernal da lógica da lei e do limite, a saber, a opção entre obediência e transgressão, apontando para uma incorporação desmetrificadora do limite e sua conversão em acesso a uma dimensão que desconhece limites.

Palavras-chave: Subsistência. Limite. Antropofagia.

\section{Abstract}

In the face of the current environmental catastrophe, the debate over limits (material, planetary) comes to the fore: how to deal with them? How to act on them? The exercise proposed here is a brief and selective cartography of the political, aesthetic, and theoretical practices that, read under the mantle of a revisited notion of subsistence and of Oswald de Andrade's Anthropophagy, constitute strategies that escape from the infernal alternative of the logic of law and of the limit, namely, the choice between obedience and transgression, and point to a de-metrifying incorporation of the limit as well as its conversion into access to a dimension that knows no limits.

Keywords: Subsistence. Limits. Antropophagy. 


\section{Introdução}

[A] reivindicação do espírito natural a que se poderia chamar o movimento do homem, paralelo ao movimento da terra. (Revista de Antropofagia, 1929)

Figura 1 - Montagem da proposição subterraneam TROPICALIA - Hélio Oiticica (1969?) Alto: babylonests, Nova Iorque/Meio: colidonescapo, Augusto de Campos/

Embaixo: Família no semiárido nordestino em foto de Carlos Vergara
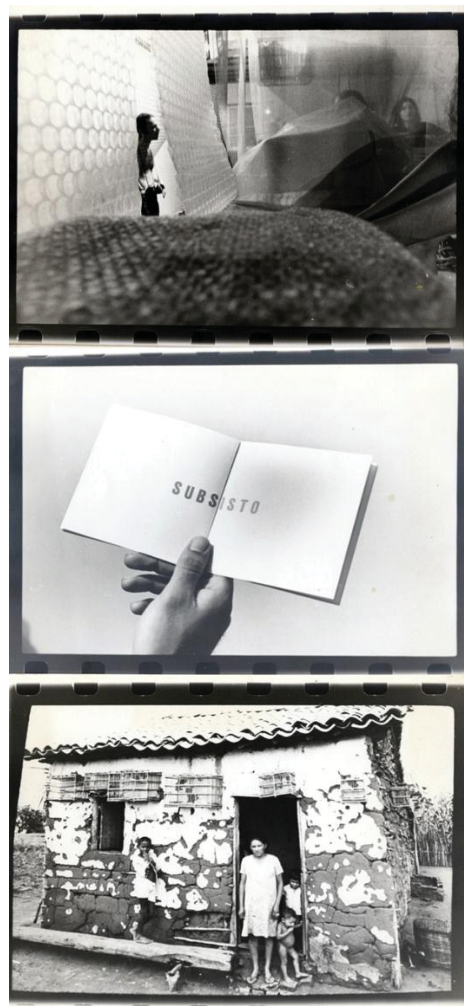

Fonte: Programa Hélio Oiticica (Itaú Cultural)

ILHA

v. 21, n. 1 , p. $68-72$, junho de 2019 
Figura 2A - "Subterrânia", de Hélio Oiticica (1969)

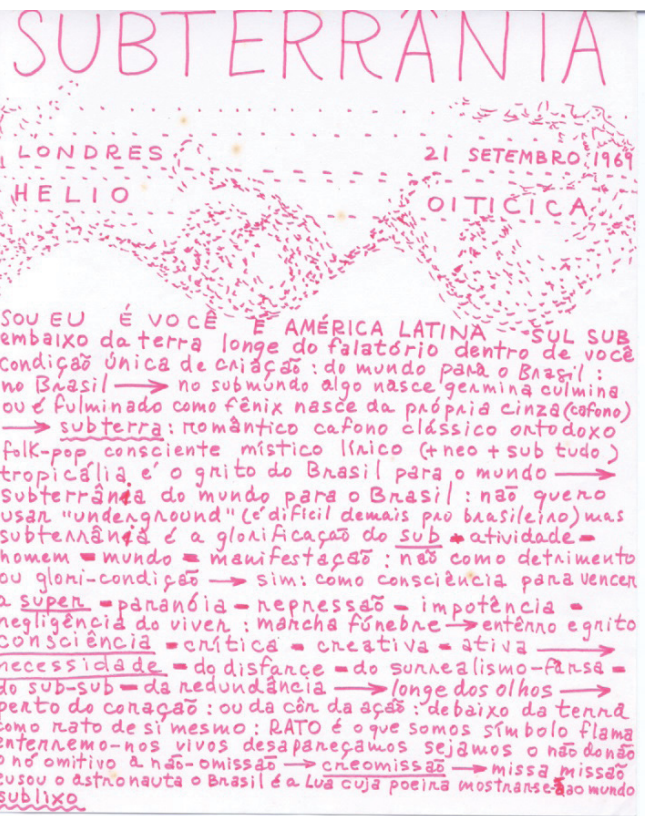

Fonte: Programa Hélio Oiticica (Itaú Cultural)

Figura 2B - "Subterrânia 2"

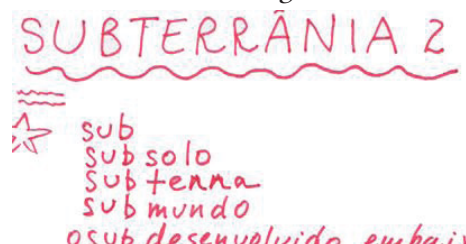

osub desenvolvido embaixoda terna cono rato

a sub América

subteriâneo do descrutuecido tena

sub fraseado

sub man

sub is ou descen no hemisfélis sul

sub verter ou corren

subliminar desejo de vencer e coustruin subaltenon gue faz sua tarefa de cobrin de

sub ténmico termómetro

subaltura

subestatuto: o suplente suplanta

suberquen

submergin pelas matas ov was ondas do man

subvéu a tua musica escondida 5060

sub way

Fonte: Programa Hélio Oiticica (Itaú Cultural)

ILHA

v. 21 , n. 1, p. $68-72$, junho de 2019 


\section{2 "Os automóveis ardem em chamas"}

Em 1968, a geração que "enfrentou o único poder que [...] ainda valia a pena enfrentar: o poder representativo da polícia com seus cassetetes e bombas de gás lacrimogêneo [...]" (Matos, 1989), entoou mundo afora uma palavra de ordem: "É proibido proibir". A fórmula, apesar da aparência, era tudo menos simples, arquitetando-se sobre uma estrutura complexa exposta por Caetano Veloso na música que a traz como título: a conjugação de uma redundância ("e eu digo sim ao sim") com uma dupla negação ("e eu digo não ao não"), realizadas conjunta e simultaneamente ("e eu digo é proibido proibir"). Assim, a proibição da proibição não se confundia com a mera transgressão, na medida em que, por um lado, afirmava em um metanível a proibição, e, por outro, propunha justamente a transgressão da transgressão. Desse modo, esses últimos revolucionários da modernidade - ou os primeiros da primavera por vir - contestavam a lógica normativa em sua própria raiz, pois, no fundo, obedecer e aplicar a lei é a mesma coisa: a transgressão da lei está contida na própria lei, o estabelecimento de um limite instaura uma dialética com o ilimitado, no qual o ultrapassamento da lei a confirma e a reforça. O exemplo mais claro de tal estrutura normativa talvez seja a estrutura do talião, uma norma de equivalência: a pena é tal qual o crime (Agamben, 2002, p. 33). A lex talionis cria uma identidade entre dois atos distintos por meio de uma economia: um olho e outro olho (a transgressão e a punição, crime e castigo) tornam-se olho por olho. Essa aparente repetição, que Alvin Gouldner (1960, p. 172) chamou de "reciprocidade negativa" ou "reciprocidade homeomórfica", constitui, na verdade, um cessar da repetição, por meio da instituição de um termo que leva a sucessão de acontecimentos (a vingança) a seu termo (a retaliação legal), i.e, por meio do estabelecimento de uma medida, uma métrica: não por acaso, o famoso adágio não é olho por olho por olho por olho..., mas olho por olho, dente por dente - não uma série infinita de atos, mas uma série finita de equivalências². Todavia, a equivalência material se ampara, para produzir seu efeito de cessação, numa ambivalência formal: o mesmo ato aparece, de um lado, como o sem-sentido, o injusto, e, de outro, como o pleno de sentido, a justiça ${ }^{3}$. Dito de outro modo, a lógica proibitiva e sua economia da transgressão 
produzem uma redução daquilo que se pode ou não fazer a um dever positivo ou negativo - e por isso Gabriel Tarde (2007, p. 106) comparou a lei a um dique dos possíveis, das diferenças. Metáfora instrutiva: os possíveis são limitados pela lei, saindo do outro lado da "barragem" como obediência ou transgressão, da mesma maneira que, numa hidrelétrica, a potência indeterminada da matéria, como a caracterizou Aristóteles, é atualizada em forma de energia, metrificada em $\mathrm{kW}^{4}$. Assim, o que estava em jogo no "É proibido proibir" era o acesso a outra configuração da vida para além (ou aquém) dessa lógica da lei, e, portanto, uma outra economia dos possíveis, como um bordão conexo deixava claro: "Sejamos realistas, demandemos o impossível".

É com esse pano de fundo que devemos ler uma série de proposições semelhantes de Hélio Oiticica, como "experimentar o experimental" e - o que nos toca mais de perto - "consumir o consumo". Essa formulação, talvez mais atual do que nunca, aparece num texto dos anos 1970, ligado ao projeto Subterrânia e sintomaticamente intitulado "Brasil Diarréia". Ali, o artista a contrapõe a duas estratégias sobre o consumo, que aparecem como dois lados de uma mesma moeda: por um lado, a negação do consumo, que gera "prisão de ventre"; por outro, o consumo desenfreado, que causa diluição, diarreia (Oiticica, 1973, p. 150). Ambas seriam modalidades do que Oiticica chamava de "super-": a repressão e o excesso, ou, em termos psicanalíticos, o super-eu paterno que castra e o super-eu materno que manda gozar, o limite e o ilimitado. Por sua vez, consumir o consumo constituiria uma operação do "subsub" que não visa nem conservar nem superar o subdesenvolvimento: enquanto forma ativa de sub-desenvolver, buscaria, antes, atacar a lógica que rege ambas essas posturas, a "convi-conivência". Ou seja, não se tratava de uma solução de meio termo, mas da dissolução dos termos por meio de sua absorção: "uma transformação radical no campo dos conceitos-valores vigentes, no comportamento-contexto, que deglute e dissolve a convi-conivência" (Oiticica, 1973, p. 152). Para Oiticica (1973, p. 150), portanto, "consumir o consumo" não significa

[...] que não se deva optar com firmeza: a dificuldade de uma opção forte é sempre a de assumir as ambivalências 
e destrinchar pedaço por pedaço cada problema. Assumir ambivalências não significa aceitar conformisticamente todo esse estado de coisas; ao contrário, aspira então a colocá-lo em questão. Eis a questão.

A assunção da ambivalência (da lei, do consumo) seria, desse modo, o que permite colocá-la em xeque, isto é, torná-la uma via de acesso à "multivalência", a "posições globais vida-mundo - linguagem - comportamento" (Oiticica, 1973, p. 148). Consumir o consumo não é consumir mais; antes, é consumir a lógica do consumo: se o consumo é sempre uma transformação, um processo digestivo, como as imagens de Oiticica sublinham, então o consumo do consumo é uma digestão desse processo, a sua dissolução e transformação em algo outro. Em "O planeta doente", Guy Debord (2011, p. 7) afirmava que a geração de 68 fez "o bom tempo", a primavera, "porque alguns carros queimaram e porque a todos os outros faltou combustível para poluir". Ela consumiu o consumo por meio do fogo da revolta.

\section{A Escassez do Excesso: gasto e indigestão}

$\mathrm{Na}$ arte de Oiticica, a prática de consumir o consumo implicava a tentativa de "estar livre das amarras do consumismo [e do espetáculo], ou seja, da demanda de produção de obras", isto é, implicava colocar "em questão o próprio problema da criação artística", visando "desintegrálo, dissecá-lo" ".5 Tratava-se, portanto, da passagem da obra e da criação (análogas ao que na economia atende pelos nomes de mercadoria e produção) aos acontecimentos (happenings), ambientes, incluindo os "ninhos" de Oiticica, como a Babylonest, "um lugar tão complicado e complexo que seja um mundo" (Oiticica apud Cera, 2012a, p. 155). A arte deixa, assim, de ser a "produção infinita de objetos" e passa a ser "a formulação de uma possibilidade de vida". Todavia, Oiticica não estava falando apenas de arte, ou melhor, estava falando só de arte, isto é, de técnica: se a guerra move as inovações técnicas ocidentais, poderíamos dizer que a arte, vanguarda militar em outro sentido, é também um manancial de inventos tecnológicos. Desse modo, ao se focar no prazer interessado do corpo, nos efeitos e no fazer - que Kant atribuía à natureza em oposição ao prazer desinteressado do julgamento, 
às obras e ao agir que caracterizariam a arte -, ele estava pensando um domínio que não se restringe à "cultura" em sentido estrito, mas "a uma coisa mais global, que envolve um contexto maior de ação (incluindo os lados ético-político-social)", o domínio da experiência: por isso, ele afirmará, ao final de seu texto sobre o consumo, que "Não existe 'arte experimental', mas o experimental" (Oiticica, 1973, p. 152). A arte, desse modo, seria uma experimentação de modos de vida, e, no caso de Oiticica, de uma forma de vida na qual seria impossível dissociar nossas técnicas de seus efeitos, o julgamento do corpo, a arte da natureza.

Todo o vocabulário digestivo do texto de Oiticica e sua ênfase no "consumo" o situam na tradição da Antropofagia de Oswald de Andrade (2011, p. 448), para quem "Nada existe fora da Devoração. O ser é a Devoração pura e eterna". A devoração universal seria, assim, a enunciação cosmológica de uma máxima da termodinâmica: na natureza, nada se cria, nada se perde, tudo se devora. Todavia, há transformações e transformações, devorações e devorações - e, assim como Oiticica, Oswald também diferenciava entre práticas de consumo, entre o que chamava de "alta" e de "baixa" antropofagia. Portanto, ao afirmar que "O que interessa [...] não é a produção e sim o consumo" (Andrade, 1990, p. 52), Oswald estava propondo um modo de diagnosticar as culturas: uma economia deve ser avaliada não só de acordo com o que ela produz, mas em relação àquilo que ela consome e à forma desse consumo. Os processos culturais (a economia geral) devem ser analisados de acordo com seu modo de digestão, o qual inclui o seu modo de produção. Por essa via, deveríamos encarar também a produção como um processo digestivo, de transformação, de consumo, ou seja, encarar uma cultura de acordo com os restos, os resíduos, pois, como afirma Elias Canetti (1995, p. 209), no “[...] excremento, que é o que resta de tudo, $[. .$.$] deixa-se reconhecer tudo quanto matamos". Desse modo,$ talvez a verdadeira face da "sociedade globalizada", esse eufemismo para a colonização do mundo pela padronização, esteja no seu lixo, no que ela gasta.

Como se sabe, a definição clássica da economia como ciência ou gerenciamento de recursos limitados/escassos para necessidades 
ilimitadas/infinitas é, na verdade, apenas a descrição da economia de mercado, a expressão do capitalismo. De fato, foi a apropriação privada (cercamentos de terras, a redução à propriedade dos inúmeros direitos reais - das coisas -, que trouxe consigo como implicação a criação da forma jurídica vazia do sujeito de direito, etc.), e, com ela, a concentração excessiva, que produziu a escassez, criando um excedente da necessidade sobre a disponibilidade: limitando o acesso, as necessidades se tornaram ilimitadas ${ }^{6}$. Essa dialética ocasionou a passagem da escassez formal (a concentração da propriedade) a uma escassez da disponibilidade material, cujo fundamento "ontológico" foi a conversão das coisas do mundo em recursos, ou seja, a "metafísica da utilidade", enunciada por Hegel (2008, p. 388): "Como tudo é útil ao homem, assim também o homem é útil a tudo"7. O sentido das coisas reduziu-se, assim, drasticamente, à sua instrumentalidade humana, e elas puderam se tornar equivalentes por meio de uma medida, a necessidade - outro nome da utilidade ${ }^{8}$. Talvez nada demonstre melhor essa redução unidimensional e unilateral do sentido que as embalagens das mercadorias (seus limites e contornos), que parecem tentar preservar o pouco de sentido que restou nelas (a utilidade), suplementando-o com uma camada nova (por meio da propaganda). O consumo capitalista começa, portanto, já nessa transformação ontológica de coisas em mercadorias, nesse esvaziamento de sentido que marca o modo de produção globalizante. O consumo propriamente dito apenas consuma esse processo, ao converter as mercadorias em lixo (waste), a saber, justamente aquilo que teve seu sentido gasto, que foi esvaziado de sentido, em todos os sentidos: significação, valor, beleza, e, por fim, a utilidade. No "Hollowcene" (expressão cunhada por Eduardo Viveiros de Castro para dar conta do Antropoceno), das palavras às coisas, tudo se gasta, incluindo aqueles homens considerados "sem-sentido" e trancafiados em prisões e manicômios. O resultado é a conversão do mundo em um imenso lixão a céu aberto - ou a céu fechado, se levarmos em consideração a camada de detritos de sucata espacial que orbita a Terra e ameaça produzir a chamada Síndrome de Kessler.

Segundo um boato corrente nos anos 1990, além da Muralha da China, a outra "construção" humana visível do espaço era o Aterro 
Sanitário de Fresh Kills, em Nova Iorque: sintomaticamente, um limite e uma wasteland. Mesmo falso, o boato trazia consigo uma profunda verdade: depositado no fundo do mar, deslocado para as periferias, o lixo é a grande produção da modernidade, e sua maior realização como obra é a Ilha de Lixo do Pacífico, espécie de anti-sopa primordial possivelmente maior que os Estados Unidos. Ou seja, o mundo foi contaminado pela indigestão consumista, fazendo da Terra um "planeta doente".

Figura 3 - Obra da série Midway: Message from the Gyre: entranhas repletas de lixo de albatrozes mortos no atol homônimo localizado no oceano Pacífico, a 2.000 $\mathrm{km}$ do continente: seus pais os alimentaram com dejetos que flutuavam no mar, tomando-os por comida

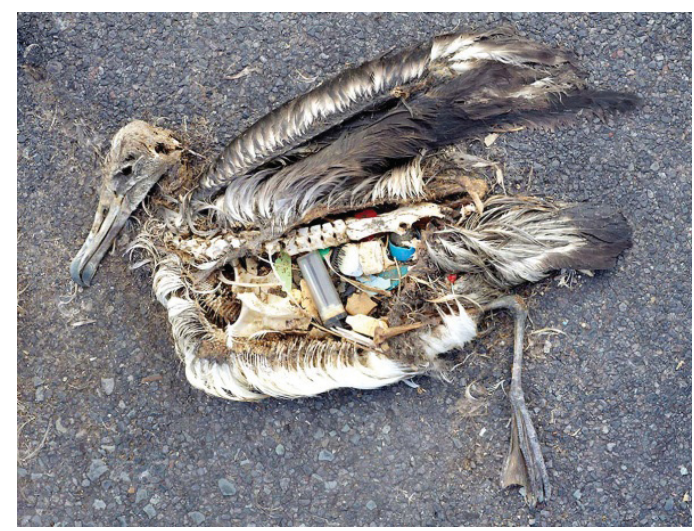

Fonte: Chris Jordan (2009-)

Nesse processo, ignorou-se a reciprocidade da transformação envolvida em toda digestão, a sua via de mão dupla: a transformação daquilo que se consome é sempre acompanhada pela transformação daquele que consome: por um lado, o luxo capitalista, o excesso, nada mais é do que a acumulação de lixo (o que transparece no famoso poema de Augusto de Campos); e, por outro, como sugerem as obras artísticas de Tim Noble e Sue Webster (nas quais detritos e resíduos são dispostos e iluminados de tal maneira que projetam sombras de seres humanos, e suas produções, como cidades, etc. ), o "projeto humano" se tornou a sombra do seu lixo - e não apenas o contrário. 
Figura 4 - Poema Luxo/Lixo

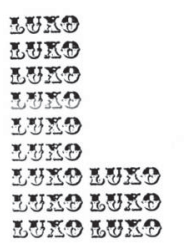

\begin{tabular}{|c|c|c|}
\hline 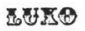 & EB] & 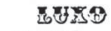 \\
\hline 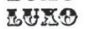 & 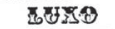 & 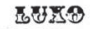 \\
\hline 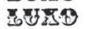 & \multicolumn{2}{|c|}{ 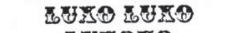 } \\
\hline 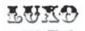 & \multicolumn{2}{|c|}{ E. } \\
\hline 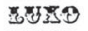 & \multicolumn{2}{|c|}{ 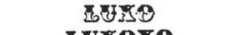 } \\
\hline$x_{3} x_{3}=9$ & \multirow{2}{*}{\multicolumn{2}{|c|}{ 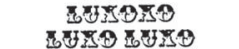 }} \\
\hline Exys9 & & \\
\hline 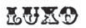 & 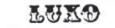 & 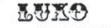 \\
\hline 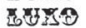 & 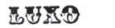 & X7X? \\
\hline
\end{tabular}

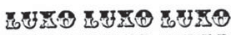

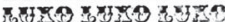

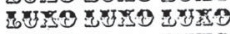

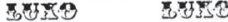

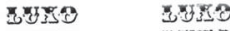

X758

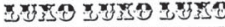

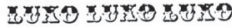

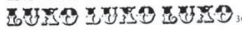

Augusto de Campos - 196.5

Fonte: Augusto de Campos (1965)

Figura 5-HE/SHE (obra composta de sucata de metal)

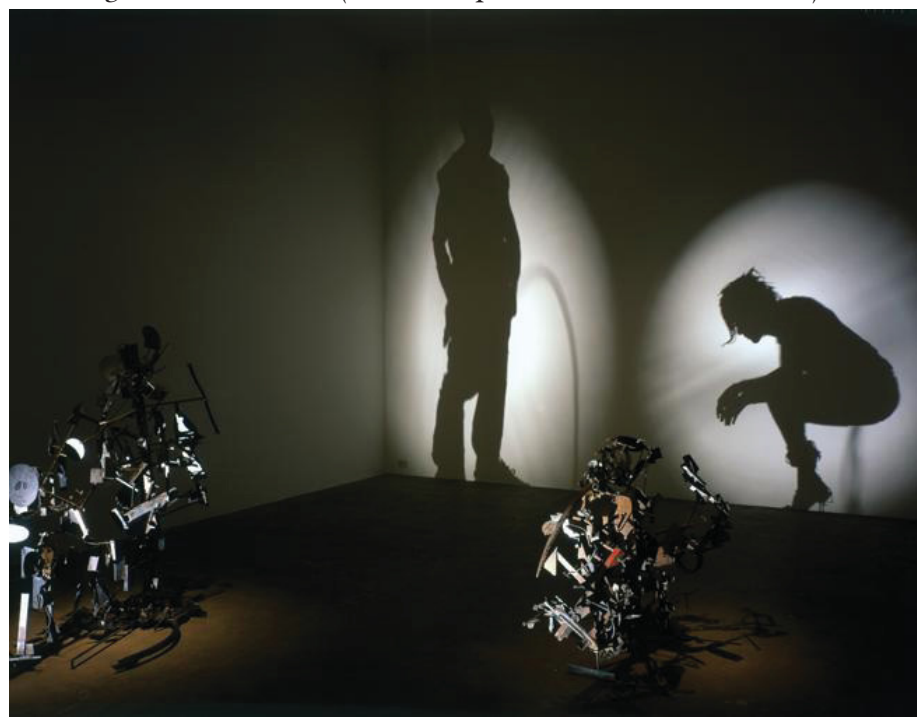

Fonte: Tim Noble e Sue Webster (2004)

ILHA

v. 21 , n. 1, p. $68-72$, junho de 2019 
Figura 6 - Dirty White Trash (with Gulls), obra feita com o equivalente a 6 meses de lixo dos artistas e duas gaivotas

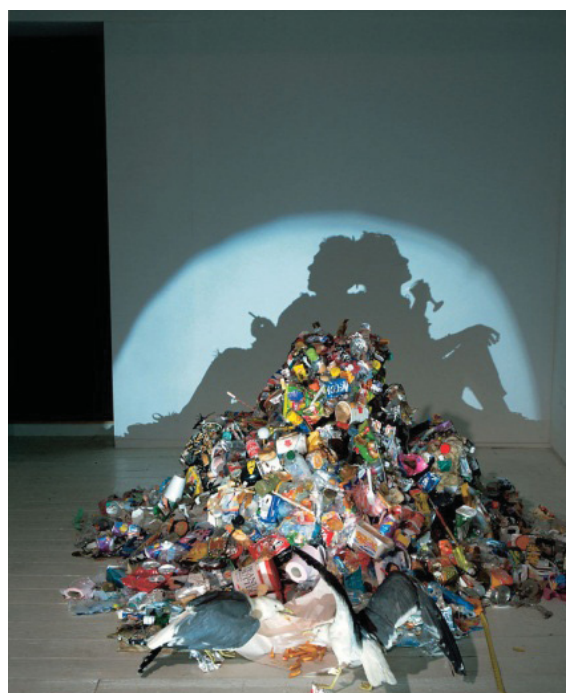

Fonte: Tim Noble e Sue Webster (1998)

Desse modo, talvez não seja um acaso que as cidades destruídas por catástrofes "naturais", portadoras do "sem-sentido" segundo Heidegger (Valentim, 2012), se pareçam muito mais com lixões do que com ruínas. Por isso, a meu ver, todo debate sobre o Antropoceno, sobre as alternativas diante da catástrofe ecológica em curso, deve partir desse cenário de terra devastada, ou seja, de um mundo esvaziado de sentido e das montanhas de lixo que continuarão aqui ainda que cessemos imediata e totalmente de gastar as coisas do mundo. Não é apenas que teremos que nos virar com pouco, como alertava Benjamin em "Experiência e pobreza": teremos que nos virar com os restos. 
Figura 7 - Tsunami de Tōhoku (Otsuchi, Japão, 2011)

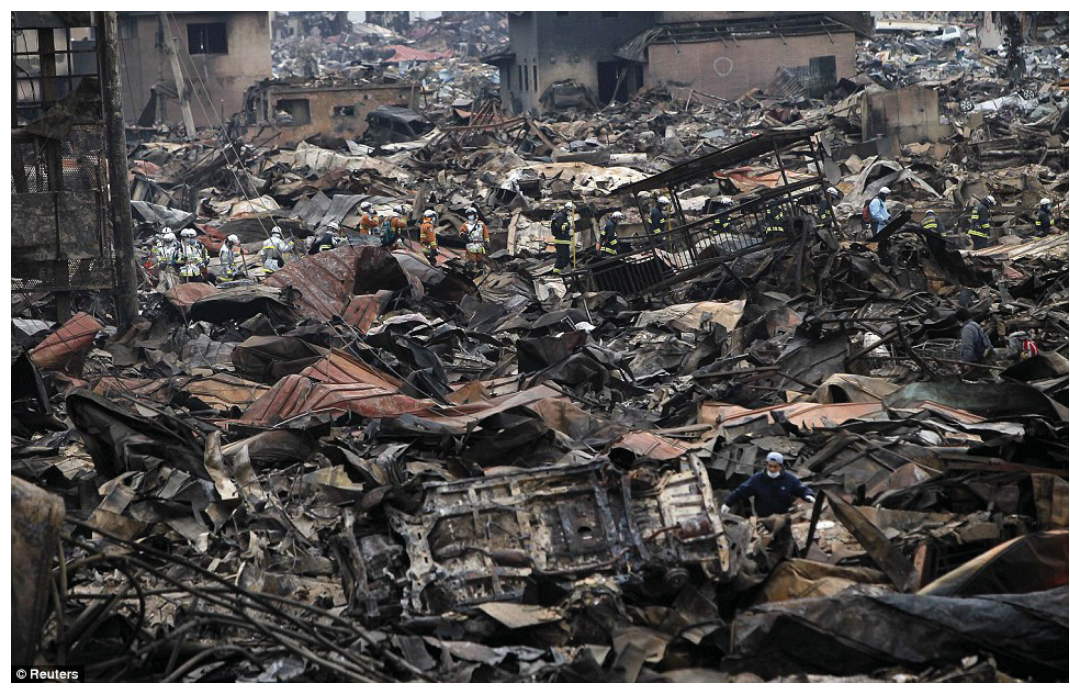

Fonte: Foto de Aly Song/Reuters (2011)

Figura 8 - Tsunami de Tōhoku (Minamisanriku, Japão, 2011)

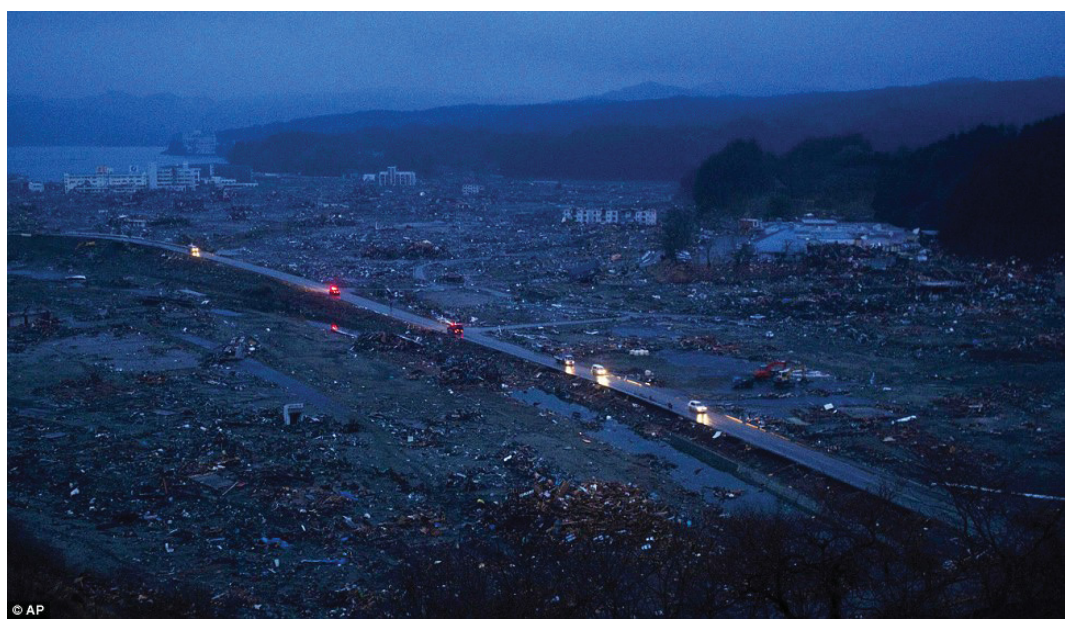

Fonte: Foto de David Guttenfelder/AP (2011) 


\section{Metrificação e Desmetrificação}

Como dissemos, Oswald contrapunha duas formas de consumo, digestão e devoração. Contra a "baixa antropofagia" do produtivismo, ele advogava uma "alta antropofagia", identificada à "subsistência". A antropofagia ritual Tupinampá lhe oferecia um paradigma em que a transformação recíproca não é apenas o resultado do consumo, mas a sua finalidade: enquanto rito de passagem, matar um inimigo na cerimônia canibal é uma forma de devir-outro, adquirir outro nome, por meio da sua incorporação e transformação (tradução) em um signo. Aqui, o consumo não esvazia de sentido aquilo (aquele) que é consumido - pelo contrário: o próprio sentido provém dele, que constitui uma relação entre sujeitos, e não entre sujeito e objeto -, e produz como resto, ineliminável, algo como um "mais-sentido", uma abertura à série infinita de acontecimentos canibais: a vingança, que fundava o ritual e que este tencionava não aplacar, como seu termo final, mas sim suscitar, uma reciprocidade não-negativa (é proibido proibir...) ${ }^{9}$.

Assim, fazendo da Antropofagia o paradigma de outro modo de consumo, Oswald de Andrade (2011, p. 154) a caracterizou como a transformação do "métrico" (a "limitação, o metro, o nomos, a lei e em geral toda a adversidade que nos encara", incluindo o "inimigo", mas também o "ambiente", a "interdição climatérica") em "nãométrico", em "valor favorável". Tomada de empréstimo ao físico Thomas Eddington, a diferenciação, semelhante àquela deleuzo-guattariana entre espaços lisos e estriados, não diz respeito a porções distintas do mundo, a uma divisão entre mundo material e mundo espiritual, mas sim a formas diferentes de experimentar o mundo: por um lado, o mundo métrico seria a perspectiva dada pela medição científica, mas também legal, econômica, ontológica etc.; por outro, o não-métrico seria a experiência que não se reduz ao (ou não é reduzido pelo) mundo dado pelos instrumentos econômico-científico-jurídico-metafísicos de medição e limitação (o sonho, a arte, etc.). Desse modo, a transformação do métrico em não-métrico não consistiria em um ultrapassamento dos limites, a superação de uma adversidade, uma saída pela transcendência, mas o acesso imanente a uma experiência desmetrificada, isto é, a algo que está antes ou aquém de todo limite. Pois se trata, justamente, de 
transformar, de consumir, de digerir o métrico, em um movimento que Oswald descrevia, a partir da Antropofagia, como uma incorporação, a "introversão objetiva" do limite: nela, o inimigo e a vingança, enquanto termos-limite - termos do limite -, são internalizados e se convertem em uma cadeia infinita da produção de sentido. Agora, dado o valor paradigmático do canibalismo ritual, como pensar um modo de prática (de consumo) que consiste em incorporar um limite, i.e., em dar corpo ao limite? E mais: como tal incorporação implica sua transfiguração em acesso ao que desconhece limites?

Um exemplo talvez nos ajude. O que é a poesia senão esse dar corpo a um limite externo, internalizá-lo objetivamente como via de acesso a uma experiência de intensidade completamente alheia ao limite? A cesura do verso, o branco da página, os pixels do monitor: a poesia, em todos os seus modos, é uma experimentação de medidas que atinge o não-métrico por meio da introversão de uma métrica, a sua conversão em um modo. É a própria limitação da extensão, ou melhor, a absorção do limite, que permite a intensificação poética. Mas a poesia não se limita àquela forma que atende pelo seu nome, sendo esta apenas o índice de todo fazer (poiesis) que transforma a limitação em intensidade, que descobre possíveis partindo de um beco sem saída. Não por acaso, é comum, na linguagem popular, que qualquer formulação ou prática intensa seja chamada de poética, de uma frase de efeito a uma jogada de Garrincha. Na poesia, um efeito máximo acontece (se faz) por um suporte material mínimo: e daí podermos chamar, como sugeriu Viveiros de Castro, de "poesia do mundo" todo fazer desse tipo ${ }^{10}$. Nela, o dar corpo ao limite coincide com uma experiência do limite e sua transfiguração em uma experiência que desconhece limites: uma experiência-limite do limite.

Aqui, cabe invocar a distinção que Deleuze (2003. p. 97-110), seguindo Bréhier, fazia entre dois tipos de limite: 
Figura 9 - Limite-contorno (limite externo, extenso)

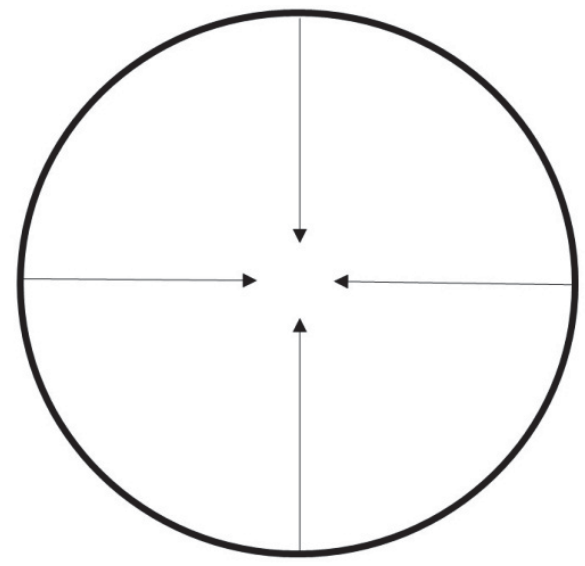

Fonte: Elaborada pelo autor deste artigo

1) Por um lado, o limite contorno, externo e transcendente, como forma que limita os corpos e impede a sua interpenetrabilidade, marcando uma extensão, e cujo movimento é do "contentor ao conteúdo, da circunferência ao centro" (Bréhier, 2012, p. 75).

Figura 10 - Limite-dinâmico (limite imanente, intenso)

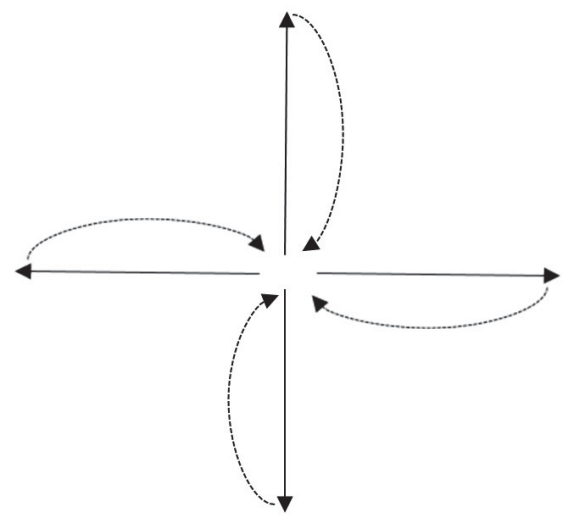

Fonte: Elaborada pelo autor deste artigo

2) Por outro, o limite-dinâmico, interno e imanente, que, na verdade, é a tensão dos corpos, a sua tendência, a sua inclinação, e, portanto, é intensivo e que não chega a uma circunferência extensa determinada, mas é um movimento de contração-di- 
latação a partir de um centro. De um lado, a forma que informa o corpo que tem lugar nesse limite; de outro, a força, a tensão do corpo que se expressa não por um contorno, mas por uma maneira de ser, de tender, por um modo (de vida), um hábito: não um lugar determinado, mas uma maneira de habitar o mundo, uma posição relacional ${ }^{11}$.

Assim como o métrico e o não-métrico, o limite externo e o interno não apontam para substâncias distintas e sim para diferentes experiências: uma que tende para a extensão-metrificação, e outra, para a intensão-desmetrificação. O que há são linhas de força, processos de metrificação e desmetrificação que se sobrepõem, se revertem, se antecipam e se conjuram uns aos outros. Se numa cultura interessa o seu consumo, o sentido de sua transformação, podemos arriscar dizer que o processo digestivo de metrificação do mundo em todas suas formas (científica, econômica, ontológica, etc.) se dá pela transformação do limite imanente em um limite-contorno, dos corpos em formas (a equivalência legal do olho por olho; a equivalência geral da utilidade; a embalagem), ou seja, constitui uma operação de delimitar o limite, colocando por extenso, à ex-tensão, uma tensão interna (a utilidade, p.ex.). Por outro lado, teríamos a operação inversa, próxima à "prática experimental da vida" situacionista, de consumir o consumo, a transformação do métrico em não-métrico, que incorpora o limite-contorno, convertendo-o em limite intenso: um modo de limitar o limite ${ }^{12}$, pelo qual a medida extensa devém uma via de contato à exterioridade, que o limite-contorno só possibilitava por meio da transgressão e do ultrapassamento. E, muitas vezes, seja na política seja na estética, essa prática pode se dar pela introdução de um limite extenso sobre outro - é proibido proibir -, perfurando-o e dando acesso à intensidade, perfurando (de e por dentro) a medida invocada por Platão contra os poetas (e um dos modos poéticos explícitos de fazêlo é pelo encavalgamento do verso, que barra a cesura - representada justamente por uma barra): 
Figura 11 - Ocupação de Belo Monte: Xingu +23 - 14 e 15 de junho de 2012 Limitar o limite: libertar o fluxo dos possíveis

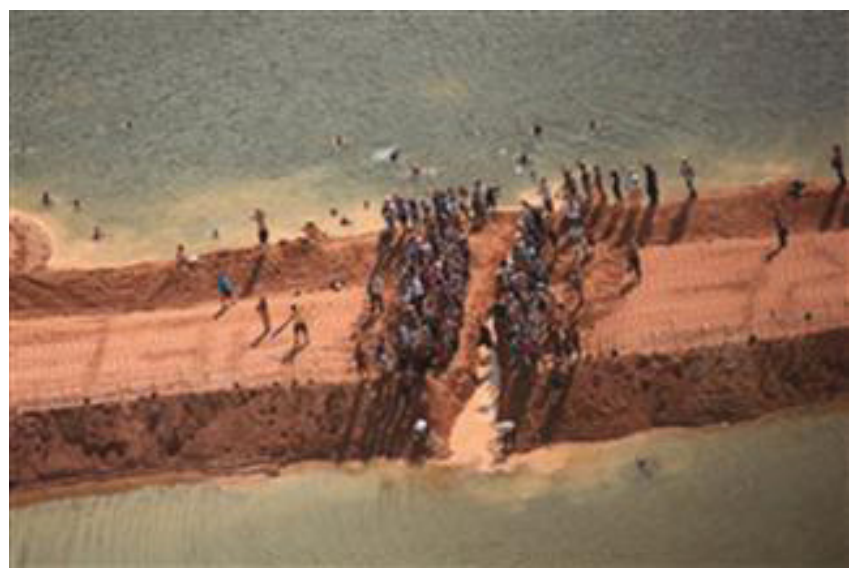

Fonte: Foto de Atossa Soltani (2012)

Figura 12 - Ocupação de Belo Monte: Xingu + 23 - 14 e 15 de junho de 2012 O limite inserido no limite é de outra ordem que o limite barrageiro: é agua, não terra - "Devolver terra à terra" (Oiticica) é também remover o aterramento dos rios

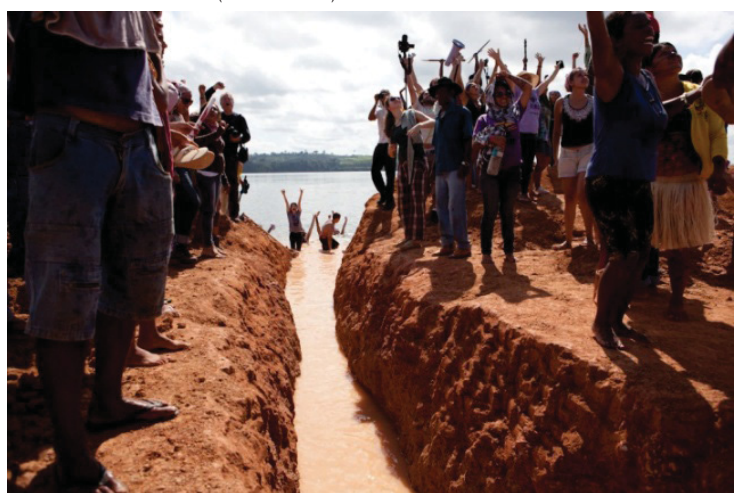

Fonte: Foto de Mitchell Anderson (2012) 
Figura 13 - Ocupação de Belo Monte: Xingu +23 - 14 e 15 de junho de 2012 Contra a metrificação da potência pela energia: produzir um efeito contra a obra

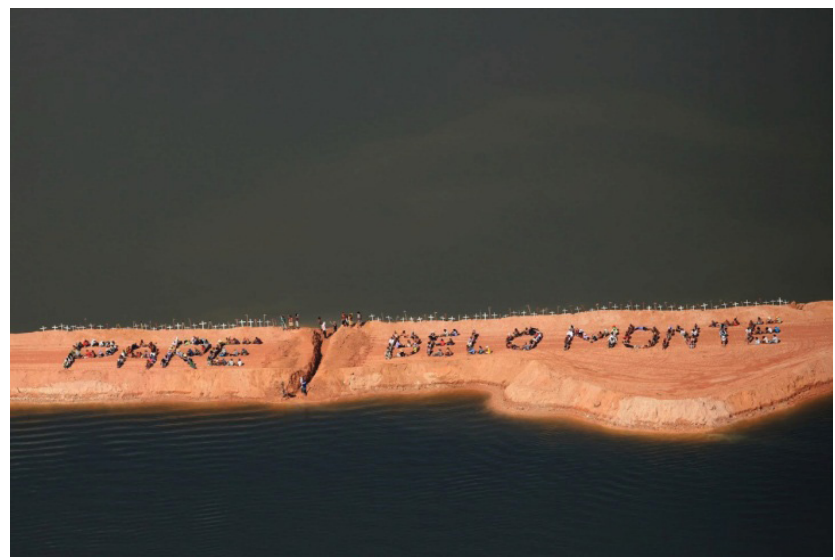

Fonte: Foto de Atossa Soltani (2012)

Figura 14 - Poema Mesóclise - Barrar a barragem: um corte oblíquo contra a ubiquidade do humano

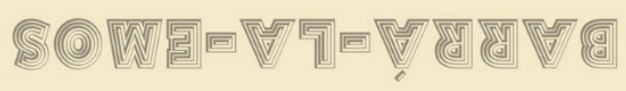

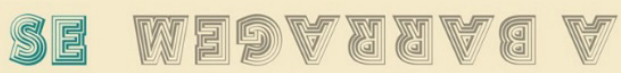

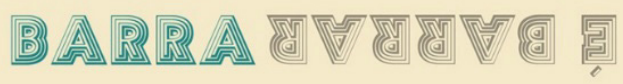

兽

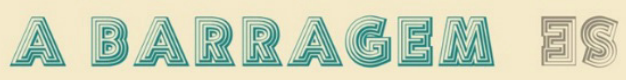

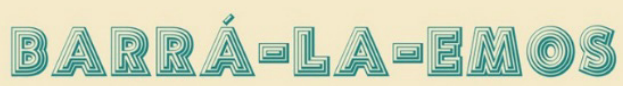

Fonte: André Vallias (2013)

ILHA

v. 21, n. 1 , p. $68-72$, junho de 2019 
Figura 15 - Limitar o limite: manifestantes fazem o "Caveirão" recuar

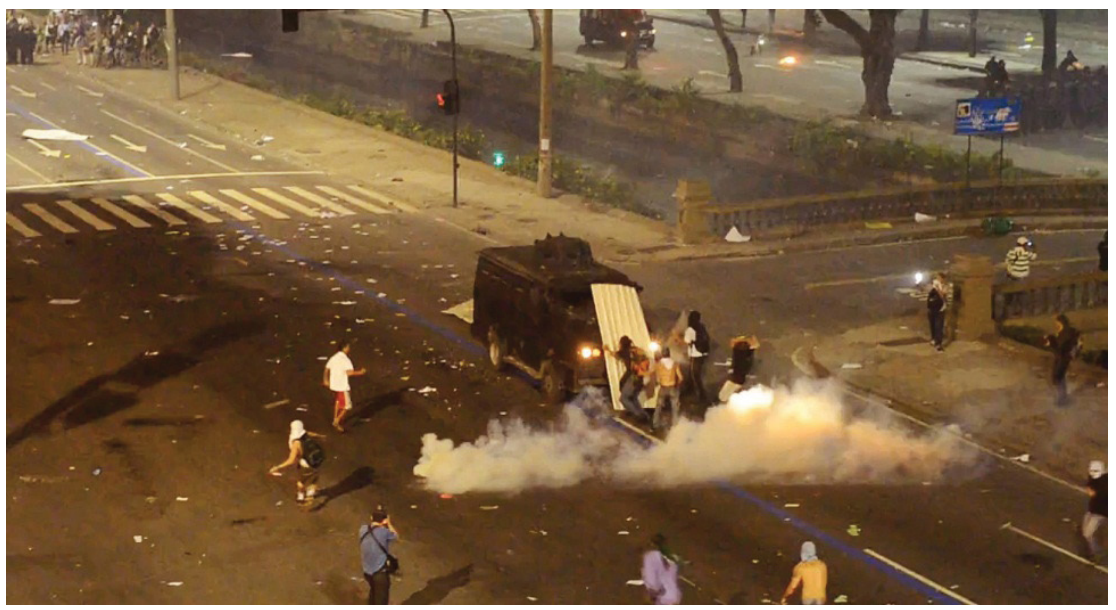

Fonte: Foto de Fernando Rabelo (2013)

Se estamos corretos, então talvez a "absorção do ambiente" de que falava Oswald ao tratar da transformação do métrico em não-métrico não constituísse uma superação da "interdição climatérica" (associada ao mundo métrico), dos limites ambientais, mas justamente um dar corpo a eles, pela sua incorporação e transformação em modo de acesso a uma experiência não-métrica com o ambiente: a experiência integral de que falava Eddington, o "eu com ambiente". Daí o sentido profundo de um trecho do Manifesto Antropófago: "Da equação eu parte do Cosmos ao axioma Cosmos parte do eu. Subsistência. Conhecimento. Antropofagia". Pois tratava-se de transformar um regime no qual o eu é uma porção delimitada do mundo, uma extensão, em outro no qual o mundo é o efeito da com-posição de sujeitos e suas intensidades, uma circunferência (inexistente) que resulta das (in)tensões combinadas de cada eu, da interpenetração dos corpos que os limites-contorno impediam. Isso que Oswald chamava de subsistência antropofágica era, portanto, um contato com a exterioridade: "O cosmos parte do $\mathrm{eu}^{\prime}$, mas "Só me interessa o que não é meu". Dito de outro modo, o mundo não existe, mas subsiste: é aquilo que está entre os seres, o interesse, a resultante de suas transformações recíprocas, o efeito de suas devorações. Só me interessa o que não é meu, ou seja, só me interessa o mundo - que parte de mim. E se o exemplo oswaldiano de consumo 
que transforma o métrico em não-métrico era a antropofagia ritual tupi, relação sujeito-sujeito, em que a devoração do corpo extenso do inimigo estava associada à adoção de um novo nome pelo matador, então poderíamos arriscar dizer que o nome adquirido por aqueles que introvertem Gaia, fazendo a partir dela uma experiência nãométrica, seja "gaiatos", e que a gaia ciência de Gaia, o conhecimento da subsistência, se chame gaiatologia.

\section{Modos de Subsistência}

A poesia do mundo, como toda poesia, tem muitos modos, mas em todos ela parece acessar uma dimensão que podemos chamar de "subsistência". Se a expressão máxima da economia da metrificação ou da metrificação da economia é o capitalismo, a sua contraparte não é o socialismo, mas as economias de subsistência das "sociedades contra o Estado". Pierre Clastres (2003) mostrou como a ausência de Estado entre os ameríndios, que aparecia aos olhos dos cronistas e da teoria política clássica enquanto falta, constituía na verdade um gesto deliberado de recusa: um "não ao não". Para Clastres (2003, p. 61), o "princípio de uma autoridade exterior e criadora de sua própria legalidade", ou seja, o princípio do poder, do limite e da hierarquia políticos, é negado por meio de algo semelhante à "introversão objetiva": a sociedade "primitiva" internaliza o Estado, na figura do chefe, para melhor "exorcizar aquilo que está destinado a matá-lo: o poder e o respeito ao poder" (Clastres, 2003, p. 216). Ao incorporar e limitar o limite, as sociedades contra o Estado ativamente constroem uma política sem hierarquia, desmetrificada. Como se sabe, essa operação envolve impedir a formação de uma esfera econômica autônoma, ou seja, envolve a manutenção de uma economia de susbsistência, entendida não enquanto defeito, mas como "recusa de um excesso" (Clastres, 2003, p. 213) de produção, ou seja, de trabalho: em um artigo clássico, Marshall Sahlins (2004) evidenciou como os grupos de caçadorescoletores, exemplo típico de economias de subsistência nos manuais de economia, não têm um modo de produção no qual se trabalha o máximo para conseguir o mínimo; sua economia, antes de ser "econômica", é de abundância, ócio e prodigalidade - o mínimo de "trabalho" para o 
máximo de "ócio". Na formulação de Deleuze e Guattari (1997, p. 130 e ss.), essa recusa se dá justamente por uma espécie de cálculo contra o cálculo: a produção e a troca nas economias de subsistência antecipa o último objeto produzido ou trocado como limite: ultrapassado, o limite se converteria em um limiar que transformaria o agenciamento em outra coisa, formando uma economia de mercado - e é esse limiar que é conjurado por meio da antecipação do limite. As economias de subsistência não são "determinadas" exteriormente pelo ambiente, nem o superam, pois ele não constitui ali um limite externo: ao limitar a produção, é a própria metrificação econômica, ou a economia da metrificação (o princípio metafísico da utilidade) que é limitada, dando lugar a uma experiência não-métrica com as coisas do mundo, com as coisas e o mundo. Não se trata apenas da fórmula oposta à da economia de mercado: recursos ilimitados, necessidades/desejos limitados, pois como todos que trabalham com economias de subsistência não cansam de repetir, uma das maiores dificuldades (ou mesmo impossibilidade) é determinar quantitativamente sua renda, quanto elas produzem e a diferença entre isso e suas "necessidades". Excesso e necessidade, trabalho e ócio, utilidade e inutilidade, produção e consumo: quando limitado o limite que separa os dois lados, seu sentido e sua relação se transformam completamente.

Mas se a subsistência designa uma experiência com o mundo, ela não se limita à política e à economia: ela se deixa ver também como uma forma de conhecimento, no que Lévi-Strauss definiu como "pensamento selvagem", em oposição ao "pensamento domesticado", a bricolagem em oposição à engenharia. Enquanto esta se caracteriza por uma "capacidade ilimitada" guiada por um projeto, aquela, fazendo uso de "'meios-limites"', trabalha por uma com-posição de materiais heteróclitos e de utensílios de um "conjunto sempre finito" (Lévi-Strauss, 1989, p. 33). De novo, aqui, estamos diante de duas experiências do limite: em relação às "limitações que resumem um estado da civilização", continua, "o engenheiro sempre procura abrir uma passagem e situar-se além, ao passo que o bricoleur, de bom ou mau-grado, permanece aquém" (Lévi-Strauss, 1989, p. 35). Por um lado, o engenheiro quer ultrapassar os limites por meio de um projeto, 
informando a matéria-prima, por meio de um novo limite-contorno. Por outro, a bricolagem trabalha a partir de um limite imanente que advém das próprias coisas, dos próprios corpos. Pois, ao operar com "resíduos de construções e destruições anteriores", ou seja, coisas aparentemente gastas, "testemunhos fósseis da história de um indivíduo ou de uma sociedade" (Lévi-Strauss, 1989. p. 37), o bricoleur não lida com coisas de sentido esvaziado, pelo contrário: as possibilidades de combinaçãol composição dos elementos na bricolagem estão "limitadas pela história particular de cada peça e por aquilo que nela subsiste", a saber, o "conjunto de relações ao mesmo tempo concretas e virtuais", e tal limitação é justamente a condição da imprevisibilidade da composição (o "acaso objetivo" surrealista, na comparação feita por Lévi-Strauss) - "cada escolha" no arranjo do bricoleur "acarretará uma reorganização completa da estrutura que jamais será igual àquela vagamente sonhada nem a uma outra que lhe poderia ter sido preferida" (Lévi-Strauss, 1989, p. 34). Ao intensificar aquilo que subsiste nas coisas, o bricoleur é reciclador radical, que não se limita a simplesmente devolver a utilidade às coisas, mas mobilizar e compor o seu sentido, como aqueles personagens de ficções apocalípticas que mobilizam os restos de um mundo devastado não apenas para novos fins, novos usos, mas também para uma nova relação com as coisas, inclusive para uma nova estética - para um devir-mundo por mais trash que seja. Se há uma ponta de esperança nos filmes catastróficos, ela não está na mera sobrevivência da espécie humana, mas na emergência de um novo sentido do mundo, das coisas do mundo, incluindo a humanidade, transformada em outra coisa: "a poesia do bricolage advém sobretudo do fato de que não se limita a 'falar' apenas com as coisas, mas também através das coisas" (Lévi-Strauss, 1989, p. 37). Como dizia Oswald de Andrade, "o lado não-métrico das coisas [...], o sonho" subsiste a todo esvaziamento:

Se a faina do homem sobre a terra é a redução do mundo não-métrico ao mundo métrico, isto é, a redução da natureza pela técnica, o mundo não-métrico ressurgirá adiante porque está no interior da própria natureza (Andrade, 1974, p. 215) 
Figura 16 - Still de Mad Max - Mobilização dos restos contra o resto de Estado (Estado Total)

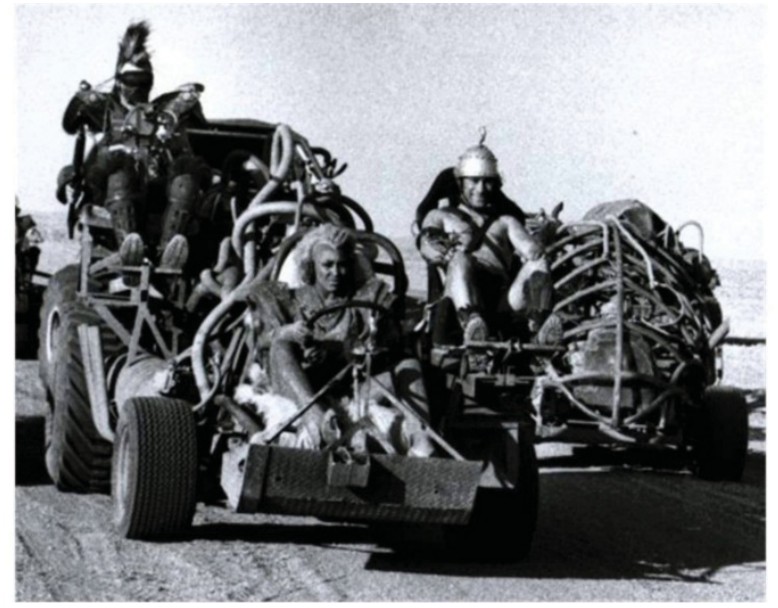

Fonte: George Miller ( 1979)

A catadora de lixo Estamira resumiu essa subsistência potente do sentido ao afirmar que "Tudo que é imaginado é, existe e tem", fórmula que talvez seja a melhor tradução para a ontologia de Meinong (2008). Ao atacar frontalmente o que chamava de "preconceito a favor do atual", Meinong optou por não tomar o real, o extenso, como parâ-metro. Antes de toda existência, indiferente a ela, tudo subsistiria objetivamente (com a mesma "dignidade" do atual): as qualidades, as relações, os modos, mas também os objetos impossíveis. Limitando o limite que separa a existência da inexistência, ele abriu acesso a uma zona ontológica do "extra-ser", do "quase-ser", habitada por toda uma rica fauna e flora que ficou conhecida como "selva de Meinong", e na qual vige uma outra ecologia do pensamento: nela, para usar uma belíssima formulação de Marcos Matos (2012, p. 3), "a riqueza material existente é infinitamente inferior à riqueza semiótica subsistente: descemos à verdade das primeiras sociedades de afluência".

\section{Subsistência dos Modos}

Tentemos sintetizar. Todos os modos de subsistência que descrevemos tendem para baixo, sub-tendem, mas para um baixo que é muito mais rico, ou muito mais intenso, que o alto: buscam, portanto, 
desenvolver para baixo, sub-desenvolver. A subsistência designa, assim, uma dimensão material e ontológica (ou contra-ontológica) baixa (a alta antropofagia leva a uma ontologia do baixo), que não pode ser quantificada: não se confunde com a mera existência, enquanto distinta de uma existência autêntica; não constitui o domínio da necessidade. Tudo o que existe também subsiste - assim como tudo o que não existe. A subsistência é o sub-solo da existência, o seu adubo, a existência em devir ${ }^{13}$. Se há uma imagem para a subsistência, é a da putrescência da matéria orgânica em toda sua riqueza vital, na qual, como plantas, tudo que existe finca suas raízes, aquele "baixo materialismo" que Bataille (2001, p. 51) dizia negar toda ontologia, por desconhecer a coisa em si, por indistinguir a matéria atual de seus possíveis: lama, não lixo - não a Wasteland esterilizada pela monocultura padronizadora, mas uma força putrefascente, como me sugeriu Felipe Vicari de Carli. Desse modo, o que a catástrofe ambiental em curso ameaça destruir não é só a existência na Terra, mas a própria subsistência, em suas dimensões material e imaterial: consumando-se o fim do mundo, não apenas os mortos não estarão a salvo, mas até mesmo aqueles que nem existiram. Daí a importância de cultivar a subsistência, pois não sendo um estado (econômico, ontológico, etc.) com uma forma dada por limites externos, ela constitui uma dimensão que se acessa ativamente pelo fazer, por uma subversão intensa, um efeito de revirar que faz algo "subvir" "de dentro pro mundo" (expressões de Oiticica). O fazer poético da subsistência é um adubamento da existência, um cultivo de possíveis, uma cultura das virtualidades e suas diferentes consistências, que não tem como parâmetro o real, nem se guia pelo privilégio do atual e da obra, e tampouco concede primazia à produção e realização, mas sim aos efeitos e aos afetos - ou seja, não constitui uma efetivação do virtual, mas um tornar palpável o (im)possível: uma "permacultura semiótica", na definição de Marcos Matos (2012, p. 4). O que se acessa por ela, portanto, não são coisas ou palavras existentes e demarcadas extensivamente, mas os efeitos e afetos das palavras e das coisas, ou seja, o sentido, aquilo que está (d)entre toda medida, entre as palavras e as coisas, entre a linguagem e os corpos, entre os seres, ou seja, aquilo que chamamos de mundo: o mundo é o sentido e o sentido éo mundo. 
Subsistir, portanto, é existir (n)o sub-, "um modo de vida subterrânio", na formulação de Flávia Cera (2012b), o que implica, porém, um fazer contra a forma-Estado (o Estado e a forma), contra o super-, o alto, seja do excesso seja da repressão, ou melhor, da lógica do limite e do ilimitado. O desafio que a catástrofe ambiental nos coloca, portanto, não é só escolher entre obedecer resignadamente aos limites materiais do planeta mantendo nossa forma de existência ou ultrapassá-los esperando uma superação dialética. Antes, ela possibilita uma solução ao mesmo tempo mais simples e mais drástica: lidar com os limites de outro modo; fazer deles uma inclinação - subvertê-los, vertê-los para baixo, in-tendê-los, tendê-los para dentro: incorporar e transformá-los em um modo intenso de vida, descobrindo toda a riqueza do baixo, fazer uma experiência do limite de máxima intensidade, uma experiência-limite do limite. Subsistir, portanto, é inserir o "sub-" na existência, fazendo desta uma existência-limite, ou seja, descer - para o mundo, “[...] devolver terra à terra para descer à terra, para re-infiltrar diversidade no subsolo, para fazê-la emergir, para inventar outros modos de vida, para começar de novo" (Cera, 2012b).

Dito de outro modo: a meu ver, não se trata de estabelecer uma lei, um Nomos, um limite externo, mesmo na forma de um direito natural ou uma lei da natureza, o que talvez seja uma contradição em termos, pois, como afirma Montaigne (1961, p. 322), "a natureza", produtora de dessemelhanças, "parece ter-se esforçado por não criar duas coisas idênticas", e a lei, ao contrário, ampara-se em uma lógica da equivalência, constituindo, como vimos com Tarde, uma barragem das diferenças (não por acaso, a lei se identifica com a morte do mundo na cosmologia de Peirce). Aquém da lei, porém, encontramos outra figura (para-)jurídica da maior relevância pro debate atual: os hábitos. Nesse sentido, Leo Strauss (2014, p. 99) argumenta que a ideia de "direito natural" depende da diferenciação entre "fenômenos naturais e fenômenos não naturais: 'natureza' é um termo de diferenciação". A distinção entre natureza e cultura é cultural, assim como a distinção entre fato e direito é criada pela lei. Todavia, Strauss parece sugerir algo mais profundo: que as duas distinções, os dois limites, estão interligados. "Antes" de tais distinções, diz ele, "o comportamento 
característico de uma coisa ou de uma classe de coisas era concebido a partir do seu costume ou do seu modo de ser" (Strauss, 2014, p. 99), ou seja, seu hábito. Os juristas tomam esse "antes" de modo evolucionista, como uma falta que pressupõe aquilo que falta: a lei. Os hábitos, nesse modo de ver, seriam uma forma de pré-Direito, a ponto de Lineu ter caracterizado os ameríndios - esses aos quais, segundo os ocidentais, tudo faltava - como os homens que se regem pelo costume, postulando na falta do direito o germe da lei. Todavia, podemos interpretar esse "'antes' das leis"" das sociedades "regidas pelo hábito" como um modo de antecipação-conjuração, uma limitação do limite, um modo de subsistência contra a lei: a lei, assim, não seria uma evolução do costume, mas sua captura e sobrecodificação. Visto sob esse prisma, o hábito não constituiria uma espécie de lei natural, uma passagem da natureza ao direito, da necessidade à convenção, mas justamente uma experiência que resulta da desmetrificação dessa distinção. Parece ser isso que está em jogo na conhecida formulação de Pascal (2005, p. 43), em que um topos clássico é levado até o limite, a ponto de ser torcionado e transformado em algo outro: "O costume é uma segunda natureza que destrói a primeira. Mas o que é natureza? Por que o costume não é natural? Temo muito que a própria natureza não passe de um primeiro costume, como o costume é uma segunda natureza". Se estamos corretos, poderíamos dizer que, ao limitar a lei e suas distinções, abre-se caminho a uma dimensão em que "ninguém tem o direito de ultrapassar um certo limite porque não há limites, mas modos de ser", oposta à do universo globalizado daqueles que

[...] inventamos e legitimamos a 'civilização' através da tecnologia, e há muito vazamos todas as fronteiras. Afinal, somos inventores e compradores de automóveis e, pior que isso, de refinarias. (DaMatta, 2014)

Dessa maneira, a guerra do Antropoceno, a guerra de Gaia, é uma guerra entre hábitos, i.e., entre formas de habitar o mundo, ou melhor, entre modos de modos de vida: aqueles hábitos codificados na lei que barra os possíveis pela "estandardização do homo sapiens" (Galvão; Ferraz, 2013), e aqueles hábitos contra a lei, hábitos de subsistência, modos de habitar o mundo que sustentam ao máximo os possíveis 
que adubam a existência. E aqui a importância da arte, daquilo que estamos chamando de poesia: pois os artistas, são, segundo Lygia Clark (1973, p. 160), justamente aqueles que "inoculam a sociedade com o vírus de um novo modo de existir": enquanto experimentação de modos, a arte é também uma moda, a (re)invenção de hábitos, de modos não-métricos de habitar o mundo, de costumes, de maneiras como nos relacionamos com e damos sentido ao mundo. A guerra de Gaia é também uma guerra estética e imaginária.

Diante da obra colidouescapo, de Augusto de Campos, poema montável de folhas soltas que se constrói interativamente pela dobragem das folhas e mistura das páginas pelo leitor, Oiticica destacou uma palavra(-de-ordem) obtida em sua leitura construtiva, "SUBSISTO", e a partir dela formulou a teoria de resistência artística de que partimos: "Subsisto seria, portanto", comenta Flávia Cera (2012a, p. 88), "uma forma de criação para resistir ao espetáculo, sub-sistir, sub-existir. Contra o espetáculo [...], subsisto é a fórmula de colocar em prática um modo de vida subterrânio". É nesse sentido que Oiticica afirmava que (dizer) "subsisto" constitui um "grito-afirmação" - e talvez hoje, mais do que nunca, se torne claro a dimensão profunda desse grito de guerra subversivo. Grito baixo, abafado pelo lixo semiótico antropodesenvolvimentista. Todavia, como dizia Clarice Lispector (1997, p. 61),

[...] um primeiro grito desencadeia todos os outros, o primeiro grito ao nascer desencadeia uma vida, se eu gritasse acordaria milhares de seres gritantes que iniciariam pelos telhados um coro de gritos e horror. Se eu gritasse desencadearia a existência - a existência de quê? A existência do mundo.

Mundo que ainda subsiste - mas não por muito tempo. Sejamos simplistas: demandemos o mais intenso. 


\section{O Primeiro e o Último, ou a "subsistência do futuro"}

"IS]ó o presente existe; o passado e o futuro subsistem, mas não existem absolutamente" (Ário).

"No tempo, o passado e o futuro são ilimitados, mas o presente é limitado" (Diógenes Láercio).

Em 1846, Henry Thoreau é preso por se negar a pagar impostos que financiariam a injusta guerra movida pelos Estados Unidos contra o México. No cárcere, ele descobre o verdadeiro sentido desse lugar onde as sociedades ditas modernas depositam aqueles homens que consideram sem-sentido:

Num governo que aprisiona qualquer pessoa injustamente, o verdadeiro lugar de um homem justo é também a prisão. O lugar apropriado hoje, o único lugar que Massachusetts proporciona a seus espíritos mais livres e menos desesperançados, são seus cárceres, nos quais se verão aprisionados e expulsos do Estado, por ação deste, os mesmos homens que já haviam expulsado a si mesmos por seus princípios. É ali que deverão encontrá-los o escravo foragido, o prisioneiro mexicano em liberdade condicional e o índio que queiram protestar contra as injustiças sofridas por sua raça; naquele lugar à parte, embora mais livre e honroso, em que o Estado coloca aqueles que não estão com ele, mas contra ele - o único lugar num Estado escravo em que um homem livre pode viver com honra. (Thoreau, 2001, p. 28-29, grifo nosso)

O efeito dessa prisão foi sua conhecida teoria da desobediência civil, uma estratégia política muito mais complexa que a mera transgressão, e que ele talvez tenha levado até o limite com sua decisão de "virar índio" (Andrade, 2007, p. 200-1), de mudar seu modo de vida e ser apenas "um hóspede da Natureza" (Thoreau, 2012, p. 47). Em um belíssimo ensaio, Virginia Wolff (2014, p. 95-96) perguntava se a "simplicidade" desse seu novo modo de vida seria "algo que vale por si mesmo" ou "antes um método de intensificação, um modo de pôr em liberdade a complicada e delicada máquina da alma, tornando-se assim seus resultados o contrário do simples?" A questão era evidentemente 
retórica: Thoreau, como poucos ocidentais, soube limitar o limite, isto é, viver no limite a partir do limite. Se, como afirma Wolff (2014, p. 101), "É difícil saber se devemos considerá-lo o último de uma linhagem mais antiga de homens, ou o primeiro de uma ainda por vir", índio ou moderno, velho que devém jovem ou moderno que devém índio, é porque talvez não se trate de uma alternativa, mas de uma experiência que desconhece a medida do tempo: o primeiro $e$ o último, o passado e o futuro, ou melhor, aquilo que está entre os dois e possibilita a subsistência de ambos. Como dizia Oiticica, "lugar: here. à beira da selva. ao largo do civilized. juntar as coisas: fazer o presente: viver: construir o futuro."

\section{Notas}

1 Uma versão resumida deste texto foi apresentada no Colóquio Os Mil Nomes de Gaia (Rio de Janeiro, setembro de 2014), e publicada na série Pandemia de cordéis, da editora n-1. O exercício de "economia geral" (para usar a nomenclatura de Georges Bataille) aqui exposto deve, mais do que seria possível expressar em palavras, ao auxílio e pesquisas de Flávia Cera (em especial, sua tese de doutorado citada adiante), a quem dedico não só este texto, mas o horizonte de um futuro possível que ele tenta sondar e que espero que possamos ajudar a construir com e para nosso filho Caetano.

2 Ou seja, se as leis talionárias precisam enunciar legalmente a relação de equivalência entre um e outro "olho", é porque ela não existe per se, sendo estabelecida judicialmente. Portanto, não há, como o esquema evolucionista do direito afirma, uma linha de continuidade entre vingança e reciprocidade negativa, ou talião (numa sequência que começaria na vingança "privada", passaria pela vingança estatal e estatizada, e chegaria finalmente na pena estatal desligada da vingança), pois elas são heterogêneas. A equivalência criada pela lei parece, assim, ser uma forma de conversão "monetária" dos hábitos, uma verdadeira moeda - e, seguindo a analogia, é como se a fase de "padrão-ouro" jurídico da lei de talião tivesse permitido o posterior acordo de Breton Woods normativo, pelo qual a Lei das Doze Tábuas dissociou a pena de seu lastro transgressivo, a desmedida que fundava a medida. Nesse ponto, se explica a "redundância" presente na fórmula "É proibido proibir": ela restabelece o desdobramento de eventos em temporalidades e níveis distintos, pois, no limite, a fórmula aponta para uma infinitude: a proibição da proibição da proibição da proibição... - nesse sentido, a fórmula tem um quê da agramaticalidade do I would prefer not to de Bartleby, assinalada por Deleuze: I would prefer not to prefer not to prefer not to...

3 Uma das definições aristotélicas de limite (peras) ilustra bem essa duplicidade equivalência-ambivalência: um ponto que divide duas retas, como terminus ad quem e terminus a quo, ao mesmo tempo discerne uma da outra e faz parte de ambas.

4 Ao contrário do que os aceleracionistas querem fazer crer, trata-se, levando-se em consideração, a partir da metafísica aristotélica, que a energia (energein, em-obra) é 
a atualização da potência, de uma redução da potência a uma unidade (um verdadeiro e contraditório devir-maior da matéria). A acumulação de energia per capita que caracteriza as sociedades ocidentais, segundo Leslie White, é, desse modo, também uma redução da potência per capita.

5 A citação provém de um manuscrito de Oiticica datado de $1^{\circ}$ de setembro de 1971 , consultado no acervo digital do artista (Programa Hélio Oiticica, mantido pelo Itaú Cultural).

6 Como argumenta Marshall Sahlins (2005, p. 565), "[a] gênese da economia foi a economia do Gênesis": a expulsão do Paraíso, a falta. O capitalismo, desse modo, é um messianismo econômico, a superação da falta, a transcendência antropotécnica pelas obras - pela produção. Além disso, antes de ingressar na economia clássica, o motivo da escassez fundamenta também o Estado moderno - a guerra hobessiana de todos contra todos é uma guerra motivada pela escassez (que só o Leviatã pode superar). Tomando um gancho de Viveiros de Castro, poderíamos dizer que a fundamentação de um excepcionalismo humano na neotenia (armadilha da qual nem Oswald, crítico voraz dos messianismos de todo tipo, conseguiu escapar) se baseia na dialética do limite e do ilimitado, que estamos descrevendo: a falta humana é o que lhe possibilita tudo - o "ser genérico" de Marx, que se diferenciaria dos outros animais justamente pela sua capacidade de projetar, ir além dos limites, como veremos.

7 Sobre isso, vale a pena ler as linhas decisivas de Bataille (2016, p. 174), que me foram indicadas por Fernando Scheibe: "Mas a apropriação pelo homem de todo recurso apropriável não se limitou aos organismos vivos. Não falo tanto da exploração recente e impiedosa dos recursos naturais (fico espantado que se percebam tão pouco os infortúnios - o desequilíbrio - que essa indústria introduz junto com a prosperidade), mas do espírito do homem em proveito do qual toda a apropriação tem lugar - diferente neste ponto do estômago, que digere os alimentos sem nunca digerir a si mesmo - que acabou ele próprio se transformando em coisa (em objeto apropriado). O espírito do homem se tornou seu próprio escravo e, pelo trabalho de autodigestão que a operação supõe, consumiu-se a si mesmo, sujeitou-se, destruiu-se. Engrenagem entre as engrenagens que dispôs, ele faz de si mesmo um abuso cujo efeito lhe escapa - na medida em que esse efeito é o de que, no fim, nada subsiste nele que não seja coisa útil. Nem mesmo Deus escapa de ser reduzido à servidão. Um trabalho de roedores vai pouco a pouco retalhando-o, atribuindo-lhe posições, depois, como tudo é móvel, constantemente remanejado, priva-o delas, demonstra sua ausência ou inutilidade".

8 Cf. as páginas iniciais de "De l'économie considérée comme magie noire", do coletivo Tiqqun, publicado no primeiro número da revista homônima. O fenômeno estético, que deriva da natural (ou produzida) indiferença das coisas em relação à distinção utilidade/inutilidade, foi também capturado pelo paradigma utilitário, por meio criação de uma esfera que tornava útil uma parcela do que se convertera em inútil com a distinção - o mesmo se passando com o ócio, cindido entre preguiça (defeito moral inútil) e status social (útil), e agora re-unificado pela sociedade do espetáculo que utiliza todo tempo livre (o verdadeiro sentido do "ócio criativo", i.e., "produtivo", de que fala certo sociólogo...). Por sua vez, o trabalho só pode ser quantificado quando autonomizado do fazer - e essa quantificação é uma redução do seu sentido, o que possibilita a mais-valia: como mostraram Deleuze e Guattari, o "trabalho" já pressupõe o sobre-trabalho. É importante lembrar que a legalização da usura pelos tribunais europeus na primeira modernidade se dá pela caracterização 
analógica do dinheiro como utensílio (ferramenta, instrumento: cf. Mathiowetz, 2007) - o que possibilitou, depois, que se tornasse o equivalente geral a todas as coisas (o utensílio universal).

9 "A reciprocidade do braço. Dentro das revelações recíprocas de hospitalidade" (Gusmão, 1929). Sobre a antropofagia como produção da vingança, de futuro e de devir, cf. Viveiros de Castro (2002, p. 181-294); para uma leitura do papel dos restos no ritual canibal (a bala do cauim, o cuspe do inimigo), cf. o capítulo de Nodari (2007, p. 124-142).

${ }^{10}$ Não se deve, evidentemente, confundir a poesia com a produção intensiva, que é uma forma de mili-metrificar a extensão, intensificar a extensão.

11 Poderíamos extrair, a partir desses dois tipos de limite, duas concepções do orgânico: 1) por um lado, o orgânico enquanto forma que molda o corpo (o orgânico enquanto pré-determinado, por genes, por ex.), que obedece a um padrão; 2) por outro, o orgânico enquanto força, enquanto fluir imanente da multiplicidade, do movimento da vida. Os aparelhos de captura ou de sobrecodificação (de vampirismo, a captura da Antropofagia) visam converter o segundo orgânico no primeiro: basta ver a padronização dos alimentos orgânicos vendidos em supermercados, quando qualquer um sabe que a variação (a variedade/diversidade mas também o apodrecimento, a presença de larvas, etc.) é o que caracteriza a agroecologia. A padronização da vida é, na verdade, uma organização da vida: a conversão do orgânico em forma, do hábito em lei (cf. abaixo), da permacultura em monocultura.

12 Trata-se da estratégia inversa a do capitalismo: "[O capitalismo] gostaria de fazer crer que se choca com os limites do Universo, com o limite extremo dos recursos e das energias. Mas ele se choca tão-somente com seus próprios limites (depreciação periódica do capital existente), e repele ou desloca apenas seus próprios limites (formação de um novo capital, em novas indústrias com forte taxa de lucro)" (Deleuze; Guattari, 1997, p. 165). Sem entrar no mérito do diagnóstico, fica claro que a operação capitalista consiste em transformar o que seria um "limite dinâmico" em um "limite externo", algo com o qual ele se choca ou deve deslocar: nela, os limites devem sempre ser ultrapassados e confrontados.

13 Para retomar e redobrar a diferenciação entre dois tipos de orgânico esboçada em nota acima, poderíamos distinguir entre uma ideia de existência orgânica, enquanto existência autêntica, oposta ao artificioso e artificial; e uma ideia de subsistência orgânica, que se opõe não ao artificial, mas ao padronizado, ao padrão (a forma que fundamenta a ideia de existência autêntica).

\section{Referências}

AGAMBEN, Giorgio. Homo sacer I: o poder soberano e a vida nua. Trad. Henrique Burigo. Belo Horizonte: EdUFMG, 2002.

ANDRADE, Oswald de. Marco Zero 2: Chão. Rio de Janeiro: Civilização Brasileira, 1974.

ANDRADE, Oswald de. Os dentes do dragão. São Paulo: Globo, 1990.

ANDRADE, Oswald de. Telefonema. São Paulo: Globo, 2007.

ANDRADE, Oswald de. Estética e política. São Paulo: Globo, 2011.

ILHA

v. 21 , n. 1, p. $68-72$, junho de 2019 
BATAILLE, Georges. A experiência interior. Trad. Fernando Scheibe. Belo Horizonte: Autêntica, 2016.

BATAILLE, Georges. Visions of excess. Minneapolis: UMP, 2001.

BRÉHIER, Émile. A teoria dos incorporais no estoicismo antigo. Trad. F. P. de Figueiredo; J. E. Pimentel Filho. Belo Horizonte: Autêntica, 2012.

CANETTI, Elias. Massa e poder. Trad. Sérgio Tellaroli. São Paulo: Companhia das Letras, 1995.

CERA, Flávia. Co-lateral: efeitos e afetos marginais. 2007. Dissertação (Mestrado em Literatura) - Universidade Federal de Santa Catarina, Florianópolis, 2007.

CERA, Flávia. Arte-Vida-Corpo-Mundo, segundo Hélio Oiticica. 2012. Tese (Doutorado em Literatura), Universidade Federal de Santa Catarina, Florianópolis, 2012a.

CERA, Flávia. Descer para baixo. Texto apresentado no evento terraterra, atividade autogestionada da Cúpula dos Povos. Casa de Rui Barbosa, Rio de Janeiro, 15 de junho de 2012b.

CLARK, Lygia. O Homem Como Suporte Vivo de uma Arquitetura Biológica Imanente. In: GULLAR, F. (coord.). Arte brasileira hoje. Rio de Janeiro: Paz e Terra, 1973.

CLASTRES, Pierre. A sociedade contra o Estado. Trad. Theo Santiago. São Paulo: Cosac Naify, 2003.

DaMATTA, Roberto. Um surto etnológico. O Globo, 30 de abril de 2014. Disponível em: https://oglobo.globo.com/opiniao/um-surtoetnologico-12338151. Acesso em: 4 maio 2019.

DEBORD, Guy. O planeta doente. Trad. Emiliano Aquino. Sopro [S.l.], n. $44,2011$.

DELEUZE, Gilles. En médio de Spinoza. Trad., para o espanhol, Equipo Editorial Cactus. Buenos Aires: Cactus, 2003.

DELEUZE, Gilles; GUATTARI, Félix. Mil platôs: capitalismo e esquizofrenia, Trad. Peter Pál Pelbart e Janice Caiafa. São Paulo: Editora 34, 1997. v. 5.

ESTAMIRA. Direção de Marcos Prado. Brasil, 2004. 121 min.

GALVÃo, Patrícia (Pagu); FERRAZ, Geraldo. A famosa revista. São Paulo: Descaminhos, 2013.

GOULDNER, Alvin. The Norm of Reciprocity: A Preliminary Statement.

American Sociological Review, [S.l.], v. 25, n. 2, 1960. 
GUSMÃO, Clóvis de. 4 pedaços do tenupá oikó. Diário da Manhã, [S.l.], 21 de julho de 1929.

HEGEL, G. W. F. Fenomenologia do Espírito. Trad. Paulo Meneses. Petrópolis/Bragança Paulista: Vozes, Editora Universitária São Francisco, 2008.

LÉVI-STRAUSS, Claude. O pensamento selvagem. Trad. Tânia Pellegrini. Campinas: Papirus, 1989.

LISPECTOR, Clarice. A paixão segundo G.H.: edição crítica. 2. ed. 1. reimp. Madrid: ALLCA XX, 1997.

MATHIOWETZ, Dean. The Juridical Subject of 'Interest'. Political Theory, [S.l.], v. 35, n. 4, p. 468-493, 2007.

MATOS, Marcos. Subsistência. Conhecimento. Antropofagia. Texto apresentado no evento terraterra, atividade autogestionada da Cúpula dos Povos. Casa de Rui Barbosa, Rio de Janeiro, 15 de junho de 2012.

MATOS, Olgária. Paris 1968: as barricadas do desejo. São Paulo: Brasiliense, 1989.

MONTAIGNE, Michel de. Ensaios. Trad., prefácio e notas Sérgio Milliet. Porto Alegre: Editora Globo, 1961. v. III.

NODARI, Alexandre. A posse contra a propriedade: pedra de toque do Direito Antropofágico. 2007. Dissertação (Mestrado em Literatura) Universidade Federal de Santa Catarina, Florianópolis, 2007.

MEINONG, Alexius. Teoría del objeto y Presentación personal. Buenos Aires: Miño y Dávila, 2008.

OITICICA, Hélio. Brasil Diarréia. In: GULLAR, F. (coord.). Arte brasileira hoje. Rio de Janeiro: Paz e Terra, 1973.

PASCAL, Blaise. Pensamentos. Trad. Mário Laranjeira. 2. ed. São Paulo: Martins Fontes, 2005.

Revista de Antropofagia: $1^{\mathrm{a}}$ e $2^{\mathrm{a}}$ dentições. (fac-simile). São Paulo: Abril/Metal Leve, 1975.

ROSE, Carol. Possession as the Origin of Property. In: ELLICKSON, Robert; ROSE, Carol; ACKERMAN, Susan Rose (org.). Perspectives on Property Law. 2. ed. Aspen: Aspen Publishers, 1995.

SAHLINS, Marshall. Cultura na prática. Trad. Vera Ribeiro. Rio de Janeiro: EdUFRJ, 2005.

SAHLINS, Marshall. Stone Age Economics. Londres: Routledge, 2004.

STRAUSS, Leo. Direito natural e história. Trad. Bruno Costa Simões.

São Paulo: WMF Martins Fontes, 2014. 
TARDE, Gabriel. Monadologia e sociologia: e outros ensaios. Tradução de Paulo Neves. São Paulo Cosac Naify, 2007.

THOREAU, Henry D. A desobediência civil. Trad. Sérgio Karam. Porto Alegre: LGPM, 2001.

THOREAU, Henry D. Walden. Trad. Denise Bottmann. Porto Alegre: LEPM, 2012.

VALENTIM, Marco A. Naturereignisse: Heidegger e o extramundano. In: WU, R.; NASCIMENTO, C. R. (org.). A obra inédita de Heidegger. São Paulo: LiberArs, 2012. p. 133-150.

VIVEIROS DE CASTRO, Eduardo. A inconstância da alma selvagem. São Paulo: Cosac \& Naify, 2002.

WOOLF, Virginia. O valor do riso. Trad. Leonardo Fróes. São Paulo: Cosac Naify, 2014.

Recebido em 03/11/2017

Aceito em 07/02/2018

\section{Alexandre Nodari}

Professor dos Programas de Pós-Graduação em Letras e em Filosofia da Universidade Federal do Paraná. Fundador e coordenador do Species - Núcleo de Antropologia Especulativa.

Doutorado em Literatura

E-mail: alexandre.nodari@gmail.com 